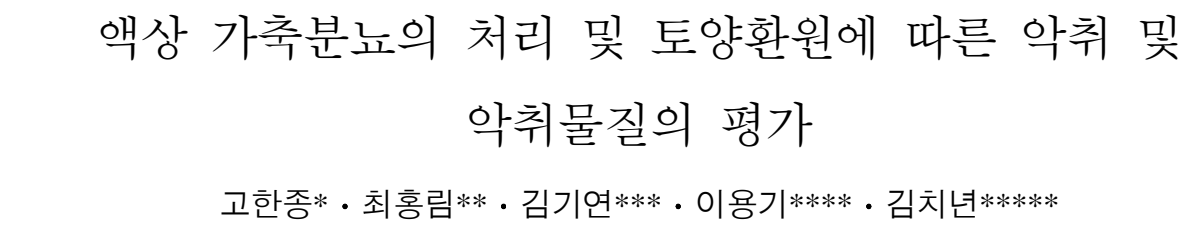

교토대학교 농학대학원*, 서울대학교 농생명공학부**, 신시내티대학교 환경보건학과*** 경기도보건환경연구원 환경연구부****, 연세대학교 산업보건연구소*****

\title{
Evaluation of Odors and Odorous Compounds from Liquid Animal Manure Treated with Different Methods and Their Application to Soils
}

\author{
H. J. Ko*, H. L. Choi**, K. Y. Kim***, Y. G. Lee**** and C. N. Kim***** \\ Graduate School of Agriculture, Kyoto University*, School of Agricultural Biotechnology, Seoul \\ National University**, Department of Environmental Health, University of Cincinnati***, \\ Kyonggi-do Institute of Health and Environmental, Environmental Research Team****, \\ Institute for Occupational Health, College of Medicine, Yonsei University*****
}

\begin{abstract}
To comply with stricter regulations provoked by increasing odor nuisance, it is imperative to practice effective odor control for sustainable livestock production. This study was conducted to assess odor and odorous compounds emitted from liquid animal manure with different treatment methods such as Fresh Manure(without treatment, FM), Anaerobic Digestion(AD) and Thermophilic Aerobic Digestion(TAD) and their application to soil. Air samples were collected at the headspace of liquid manure, upland and paddy soil, and analyzed for odor intensity and offensiveness using an olfactometry; odor concentration index using odor analyser; nitrogen-containing compound such as ammonia( $\left(\mathrm{NH}_{3}\right)$ using fluorescence method; and sulfur containing compounds such as hydrogen sulfide $\left(\mathrm{H}_{2} \mathrm{~S}\right)$, methyl mercaptan(MeSH), dimethyl sulfide(DMS) and dimethyl disulfide(DMDS) using gas chromatography-pulsed flame photometric detector, respectively. Odor intensity, offensiveness and concentration index from TAD liquid manure was statistically lower than those from $\mathrm{FM}$ and $\mathrm{AD}(\mathrm{p}<0.01)$. Mean concentrations of $\mathrm{H}_{2} \mathrm{~S}$, MeSH, DMS, DMDS and $\mathrm{NH}_{3}$ were $65.93 \mathrm{ppb}$, $18.55 \mathrm{ppb}, 5.26 \mathrm{ppb}, 0.33 \mathrm{ppb}$ and $10.57 \mathrm{ppm}$ for liquid manure with $\mathrm{AD}$; and $5.15 \mathrm{ppb}, 0.97 \mathrm{ppb}, 0.80 \mathrm{ppb}$, $0.56 \mathrm{ppb}$ and $1.34 \mathrm{ppm}$ for liquid manure with TAD, respectively. More than $60 \%$ of malodorous compounds related to nitrogen and sulfur were removed by heterotrophic microorganisms during TAD treatment. When liquid manure was applied onto upland and paddy soil, $\mathrm{NH}_{3}$ removal efficiencies ranged from 51 to $94 \%$ and 22 to $91 \%$ for $\mathrm{AD}$ and $\mathrm{TAD}$ liquid manure, respectively. The above results show that liquid manure with $\mathrm{TAD}$ is superior to $\mathrm{AD}$ and $\mathrm{FM}$ with respect to the odor reduction and odor problem caused by land applied liquid manure is directly related to the degree of odor generated by the manure treatment method.

(Key words : Olfactometry, Odor intensity, Odor offensiveness, Ammonia, Sulfur containing compounds, Liquid manure)
\end{abstract}

Corresponding author : H. J. Ko, Graduate School of Agriculture, Kyoto University, Kyoto 606-8502, Japan. E-mail : khjong333@hanmail.net 


\section{I. 서 론}

상대적으로 제한된 면적에서 사육형태가 집 약적이고 기업화됨에 따라 축산농가에서 발생 되는 대량의 가축분뇨 적정처리와 악취문제에 대한 방지대책이 지속적 축산을 영위하기 위한 필수적인 선결과제가 되었다. 악취는 쾌적한 삶의 질 향상을 추구하려는 주민의 욕구와 도 농간(Urban and Rural) 공간적 거리가 점차 줄 어들어 지속적으로 악취 민원 발생이 증가하고 있으며, 이와 관련되어 정부에서는 기존의 대 기환경보전법에서 다루었던 악취관련 부분을 따로 독립시켜 더욱 강화된 악취방지법을 2005 년 2월부터 시행하고 있다(환경부, 2005). 한 편 축산농가에서 발생된 가축분뇨가 수질오염 및 악취 발생원과 같은 오염원이 아닌 양질의 유기질비료로 가공하여 친환경농축산물 생산이 가능하도록 한 친환경 농업이 제시되었고(농림 부, 1997), 친환경 농법으로 재배된 농산물의 생 산과 소비는 지속적으로 증가되고 있는 실정이 다. 이처럼 자연순환에 입각한 경종-축산연계 체계의 중심은 가축분뇨의 퇴·액비화(composting \& liquid fertilizer) 이용이라고 할 수 있다(농협 중앙회, 2002; 한국유기농업학회, 2003; 축산 관련단체협의회, 2003). 그러나 축산에서 발생 할 수 있는 악취관련 민원 중 가장 큰 비중을 차지하는 부분이 분뇨를 농경지에 환원할 때 발생할 수 있으며(Hardwick, 1985; Pain, 1995; Jacobson 등, 1998), 축사나 분뇨 저류조에서 발 생되는 저농도의 악취와 달리 고농도의 악취가 단시간에 방출되기 때문에 이에 대한 효과적인 저감 대책을 실행하지 못한다면 악취 민원으로 인한 가축분뇨의 농업적 재활용이 어려울 수밖 에 없다.

가축분뇨의 액비화 목적은 작물 생육에 장해 가 없도록 부숙(maturity)시키는 동시에 분뇨에 서 발생되는 악취를 제거하기 위함인데 액상 가축분뇨의 처리방법에 따라 악취발생의 차이 가 나타난다. 일반적으로 적용되고 있는 액비 화 방법은 혐기성 소화(anaerobic digestion)를 이 용한 단순저장 액비화 및 폭기처리에 의한 호 기성 소화(aerobic digestion)로 구분할 수 있으
며, 악취제거 측면에서는 호기성 소화가 우수 한 것으로 알려져 있다(Williams 등 1989; Pain 등 1990; Svoboda, 1995). 그러나 현장에 설치된 대부분의 액비 저장조의 폭기 장치가 저장용량 에 적합하지 않거나, 제대로 가동이 되지 않아 저장된 액비의 호기적 조건을 형성하지 못하고 혐기성 상태로 유지되고 있어 이러한 액비를 농경지에 살포시 악취 휘산으로 인한 민원 발 생의 소지가 많아 액비의 이용활성화에 큰 제 약으로 작용하고 있다(농업과학기술원, 1999; 농협중앙회, 2002; Rappert 및 Muller, 2005). 혐 기성 저장 액비에서 악취가 심한 원인은 분뇨 유래 악취물질 중 최소감지농도(Odor threshold value)가 낮은 황(S)을 포함하는 악취물질들이 혐기성 상태에서 미생물의 작용으로 생성되기 때문이다(O'Neill 및 Phillips, 1992; Hao 등, 1996).

현재까지 분뇨를 토양에 살포할 때 발생하 는 악취 휘산을 줄이기 위해 살포방법이나 첨 가제를 이용한 전처리 방법 등에 관한 연구들 (Lorimor 등, 2002; Rappert 및 Muller, 2005)이 수행되었으나 액상분뇨의 처리 및 토양 특성이 다른 농경지에 환원시 발생하는 악취 평가에 대한 연구는 미비한 실정이다. 따라서 본 연구 는 가축분뇨의 액비화 이용시 처리방법이 다른 액상분뇨에서 발생되는 악취 및 이러한 분뇨를 논 - 밭 토양에 살포했을 때 방출되는 악취 및 악취물질을 평가하고자 수행하였다.

\section{ㅍ. 재료 및 방법}

\section{1. 시험 설계}

본 연구에서 사용된 가축분뇨는 육성 - 비육 단계의 돼지에서 발생된 돈분뇨를 원료로 하였 으며, 액상분뇨 처리는 슬러리 돈사에서 저류 조로 이송된 아무런 처리를 하지 않은 신선 돈 분뇨(fresh manure), 미생물제제의 첨가나 일부 폭기처리를 하였지만 호기성 조건을 유지하지 못해 통성-절대 혐기성 조건을 거친 혐기성 소화 분뇨(anaerobic digestion manure) 및 지속 적인 폭기처리에 의한 호기적 조건으로 미생 
물의 자체 산화열을 유지하며 유기물을 소화 시킨 고온 호기성 소화 분뇨(thermophilic aerobic digestion manure) 3 가지로 분류하였다. 또한 처 리방법이 다른 액상분뇨를 토양 특성이 다른 논과 밭 토양에 살포했을 때 악취발생 및 저감 양상을 평가하기 위해 서울대학교 부속농장의 논 시험포장과 부속목장의 밭 시험포장에서 채 취한 토양을 이용하였다. 공시 토양은 분뇨 살 포시 토양 투과성을 고려하여 표토층(top soil) 인 $20 \mathrm{~cm}$ 내외의 토양을 적용하였다. 따라서 본 연구는 액상 가축분뇨의 액비화 처리방법과 처 리된 액상분뇨를 특성이 다른 토양에 살포했을 때 발생되는 악취를 평가하기 위해 Table 1에 서 보는 바와 같이 6처리 5반복으로 설계하였 다.

Table 1. Description of experimental design

\begin{tabular}{|c|c|c|}
\hline Treatment method & Soil type & Replication \\
\hline \multirow{2}{*}{ Fresh manure } & upland & 5 \\
\hline & paddy & 5 \\
\hline \multirow{2}{*}{ Anaerobic digestion } & upland & 5 \\
\hline & paddy & 5 \\
\hline \multirow{2}{*}{$\begin{array}{l}\text { Thermophilic aerobic } \\
\text { digestion }\end{array}$} & upland & 5 \\
\hline & paddy & 5 \\
\hline
\end{tabular}

\section{2. 주요 악취발생 원인물질 선정}

가축분뇨에서 발생되는 악취물질들은 주로 유기물의 불완전한 혐기분해에 따른 휘발성 복합 화합물이기 때문에 이들 전체 악취발생 원인 물질을 규명하고, 정량적 분석을 수행하 여야 하나 정밀도와 신뢰성을 담보할 수 있는 분석장비와 기술에 한계가 있다. 따라서 기존 의 연구자들이 분뇨 저장 및 토양살포의 과정 에서 방출되는 주요 악취물질(Mackie 등, 1998; Whitehead 및 Cotta, 2004)이라고 보고한 물질 들 중 질소화합물 악취물질이며, 축산에서 발 생되는 대표적인 악취물질로 간주되고 있는 암모니아 $\left(\mathrm{NH}_{3}\right)$ 와 분뇨의 저장 및 처리 조건에 따라 방출 양상이 차이가 심하고, 최소감지농 도가 매우 낮은 황화합물 악취물질인 hydrogen sulfide $\left(\mathrm{H}_{2} \mathrm{~S}\right)$, methyl mercaptan(MeSH), dimethyl sulfide(DMS) 및 dimethyl disulfide(DMDS)를 악 취 원인물질로 선정하였다.

\section{3. 시료 포집}

가축분뇨의 액비화 처리방법에 따라 분뇨에 서 방출되는 악취 및 악취물질 분석을 위해 30 $\ell$ 의 원통형 jar에 액상분뇨를 투입하고 차광 비닐 필름으로 밀봉한 후 $40 \ell$ 의 무취가스를 주입시켰다. 분뇨의 투입량 결정에 앞서 액상 분뇨 중의 질소 함량(신선분뇨 $1.1 \%$, 혐기성 소 화 액상분뇨 $0.5 \%$, 고온 호기성 액상분뇨 $0.2 \%$ ) 을 분석한 후 벼와 보리의 표준시비량인 $12 \mathrm{~kg}$ $/ 10 \mathrm{a}$ 에 해당되는 질소성분 당량을 계산하여 각 각의 액상분뇨의 투입량을 결정하였다. 또한 시료 포집시 발생할 수 있는 온도, 풍속 등의 기상 조건에 의한 영향을 최소화하기 위해 환 경조건이 동일한 실내에서 밀폐된 jar에 무취 가스를 주입한 직후에 시료를 채취하였다. 악 취 강도 및 불쾌도를 관능법으로 평가하기 위 해 액상분뇨의 headspace에서 syringe를 이용하 여 시료를 채취하였고, 암모니아를 분석하기 위해 흡수액 $(0.1 \mathrm{~N}$ sulfuric acid, $10 \mathrm{ml})$ 을 넣은 impinger와 moisture trap을 air sampler(Gil-Air NO. 800519, Gillian Instrument Corp, USA)에 연결하여 $1.7 \mathrm{l} / \mathrm{min}$ 의 유량으로 10 분간 채취하 였다(NIOSH, 1994). 또한 황화합물 악취물질을 분석하고자 폴리프로필렌 필름으로 만들어진 테들러 백(Tedlar bag, SKC, USA)을 시료채취용 기로 선정하고, 시료를 채취하기 전에 질소가 스로 2 회 세척과정을 거쳐 시료를 $1 \sim 2 \ell / \mathrm{min}$ 의 유량으로 5 분간 $10 \ell$ 테들러 백에 채취하였 다. 앞서 언급하였지만 밀폐된 jar에 $40 \ell$ 의 무 취공기를 주입하였기 때문에 시료를 채취하면 서 발생될 수 있는 내부의 압력변화나 외부공 기의 유입분과 같은 분석오차를 유발할 수 있 는 요인들의 영향은 극히 미미한 것으로 사료 되었다. 액상분뇨를 사양질 토성인 논 토양과 식양질인 밭 토양에 살포시 악취발생 및 저감 정도를 평가하기 위해 $30 \ell$ jar에 $20 \mathrm{~cm}$ 깊이로 토양을 충전시킨 후 액상분뇨를 살포하였다. 
또한 악취분석을 위한 시료 채취의 조건과 방 법은 전술한 액상분뇨 유래 악취평가에 적용한 방법과 동일하게 수행하였다.

\section{4. 분석 방법}

1) 악취 강도, 불쾌도 및 악취 농도 측정

관능법에 의한 악취 평가 방법으로 본 연구 에서는 악취 강도(odor intensity)와 불쾌도(odor offensiveness)를 선택하여 평가하였다. 악취 평 가의 신뢰성을 확보하기 위해 후각 기능이 정 상적인 악취 판정원을 대상으로 후각 측정시 표준물질이라 할 수 있는 아세트산에틸에 정상 적으로 반응하는 5 명의 악취 판정원을 선정한 후 무취실에서 채취된 시료를 평가하는 직접 관능법을 적용하였다. 악취 판정원들의 결과는 최고 상한치와 하한치를 제외한 3명의 점수를 기하 평균하여 표시하였다. 악취 강도 및 불쾌 도는 6단계 악취 강도 표시법과 5단계 악취 불 쾌도 표시법을 이용하였는데, 악취 강도와 불 쾌도 모두 0 은 무취(no odor) 또는 불쾌하지 않 은 냄새(not offensive)이며 냄새가 심할수록 강 도가 높아져 악취 강도 5 는 참을 수 없는 강렬
한 냄새(very strong), 악취 불쾌도 5는 극단적 으로 불쾌한 냄새(very strongly offensive)로 분 류하였다(양 및 이, 1997; Roderick 등, 1998). 악취 농도 지수(odor concentration index) 측정 은 휴대용 디지털 악취 농도 측정기(XP-329, Cosmos instrument, Japan)를 이용하여 3회 측정 한 평균값을 이용하였다.

\section{2) 암모니아 농도 분석}

흡광광도법으로 암모니아를 분석하기 위해 암 모니아 흡수액으로 황산 $\left(\mathrm{H}_{2} \mathrm{SO}_{4}\right)$ 을 이용하였으며, 10 분간 gas를 흡입한 흡수액을 여과 후 적정

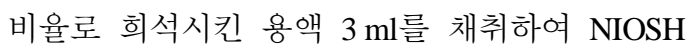
공정시험법(1994)에서 제시한 발색시약(nessler's agent) $0.2 \mathrm{ml}$ 를 첨가한 후 spectrophotometer (UV1601 , SHIMADZU, Japan)를 이용하여 440nm 파 장에서 측정하였다. 검량선은 암모니아 표준용 액으로 황산암모늄 $\left(\left(\mathrm{NH}_{4}\right)_{2} \mathrm{SO}_{4}\right)$ 을 이용하여 0,2 , $4,8,12,16 \mu \mathrm{g} / \mathrm{ml}$ 농도를 설정한 후 식(1)과 (2) 에 의해 암모니아 농도를 계산하였다. 또한 공 시료의 경우 분석시료와 함께 같은 조건으로 분석하였다.

Table 2. GC-PFPD and UNITY conditions used for determining the concentration of Sulfur containing compounds

\begin{tabular}{lcc}
\hline Instrument & Analysis condition \\
\hline \hline & Detector & PFPD \\
Column & CP-5 $(60 \mathrm{~m} \times 0.25 \mu \mathrm{m} \times 1.0 \mu \mathrm{m})$ \\
Carrier Gas & He $1.0 \mathrm{ml} / \mathrm{min}$ \\
GC-PFPD & Air-1 Flow Rate & $17 \mathrm{ml} / \mathrm{min}$ \\
& Air-2 Flow Rate & $10 \mathrm{ml} / \mathrm{min}$ \\
& $\mathrm{H}_{2}$ Flow Rate & $13 \mathrm{ml} / \mathrm{min}$ \\
& Oven Temp & $220^{\circ} \mathrm{C}$ \\
\hline Detector Temp & $60^{\circ} \mathrm{C}(5 \mathrm{~min})-10^{\circ} \mathrm{C} / \mathrm{min}-200^{\circ} \mathrm{C}$ \\
Thermal Desorption Unit & Sampling Time & $25 \mathrm{ml} / \mathrm{min} \times 4 \mathrm{~min}$ \\
& Cold trap Temp & $-15^{\circ} \mathrm{C} \mathrm{high} \mathrm{:} 280^{\circ} \mathrm{C}$ \\
& Hold Time & $5.0 \mathrm{~min}$ \\
& Outlet split & $10.0 \mathrm{ml} / \mathrm{min}(10: 1 \mathrm{split}$ ratio $)$ \\
& Flow path Temp & $100^{\circ} \mathrm{C}$ \\
\hline
\end{tabular}


$\begin{aligned} & \mathrm{NH}_{3} \\ & \left(\mathrm{mg} / \mathrm{m}^{3}\right)\end{aligned}=\frac{\text { 농도 }(\mathrm{B}-\mathrm{A}) \times \text { 흡수용액 }(\mathrm{ml})}{\text { 유량 }(\ell)}$
$\underset{(\mu \mathrm{l} / \mathrm{l})}{\mathrm{ppm}}=\left(\mathrm{mg} / \mathrm{m}^{3}\right) \times \frac{24.45}{\mathrm{NH}_{3} \text { 분자량 }(17.03)} \times \frac{760}{\mathrm{P}} \times \frac{\mathrm{T}+273}{298}$ (2)

여기서, B : 시료의 농도 $(\mathrm{ug} / \mathrm{ml})$

$$
\begin{aligned}
& \mathrm{A} \text { : 공시료의 농도 }(\mathrm{ug} / \mathrm{ml}) \\
& \mathrm{P} \text { : 측정시 대기압 }(\mathrm{mmHg}) \\
& \mathrm{T} \text { : 측정시 온도 }\left({ }^{\circ} \mathrm{C}\right)
\end{aligned}
$$

\section{3) 황화합물 농도 분석}

황화합물 악취물질인 $\mathrm{H}_{2} \mathrm{~S}, \mathrm{MeSH}, \mathrm{DMS}$ 및 $\mathrm{DMDS}$ 를 분석하기 위해 채취된 시료를 즉시 분석실로 운반하여 일차적으로 시료 중에 극미 량으로 존재하는 악취성분을 열 탈착기(Thermal desorber)와 가스 분배기(Air server)가 결합된 열 탈착시스템(Thermal Desorption Unit, U-UNITYe, Markes international, UK)을 이용하여 농축하였 다. Air server를 통하여 흡착이 이루어진 시료 는 $330^{\circ} \mathrm{C}$ 의 온도에서 5 분간 열탈착이 이루어지 고, 탈착이 이루어진 시료는 시스템 내부에서 다시 GC의 column으로 주입되었다. 시료의 전 처리에 이용된 UNITY와 황화합물 분석에 사용 된 GC-PFPD(Gas chromatography with Pulsed Flame Photometric Detector, CP-3800, VARIAN, USA)의 조건은 Table 2와 같다.

\section{5. 통계 분석}

통계처리는 SAS package program(1999)을 이 용하여 분산분석을 실시하였으며, 처리 평균간 비교는 최소 유의차검정(LSD)을 이용하여 분석 하였다.

\section{III. 결과 및 고찰}

1. 처리방법에 따른 액상분뇨의 악취 강도, 불쾌도 및 농도 평가

처리방법이 다른 액상분뇨의 악취 강도(odor intensity), 불쾌도(odor offensiveness) 및 농도(odor concentration index)에 대한 결과를 Table 3에 나타내었다. 액상분뇨의 처리방법에 따라 악취 판정원들이 느끼는 악취의 강도 및 불쾌도가 차이를 보였는데, 아무런 처리를 하지 않은 신 선분뇨 및 혐기성 소화 액상분뇨는 고온 호기 성 소화 액상분뇨에 비해 악취 강도, 불쾌도 및 농도의 모든 항목에서 높았으며 통계적으로 도 고도의 유의적인 차이를 보이는 것으로 측 정되었다. 고온 호기성 소화로 처리된 액상분 뇨는 돈슬러리 특유의 악취를 감지할 수 없을 정도로 악취 저감 효율이 높은 것으로 판단되 나 다른 처리는 악취가 저감되지 않았고, 이러 한 액상분뇨를 농경지에 환원시킨다면 악취 민 원의 소지가 높을 것으로 사료되었다.

가축분뇨를 유기질 자원으로 이용하기 위한 친환경농업 육성법 공포와 유기농 - 축산 발전 등의 활발한 움직임과 현장에서의 연계체계 필 요성에 의해 2002년 비료관리법에서 가축분뇨 비료(액)의 규격을 신설하게 되었다(농촌진흥 청, 2006). 이는 액비의 농업적 이용과 환경오 염 방지라는 두 가지 측면을 고려한 개정이라 고 할 수 있으며, 신설된 가축분뇨발효비료(액) 의 규격에서는 대기환경보전법의 악취발생 제 한 규정에 의거한 악취 강도 2 수준의 냄새에 대한 규격을 명시하고 있다. 본 연구에서 조사 분석된 액비를 비료관리법 공정규격에 적용한

Table 3. Comparison of odor intensity, offensiveness and concentration index emitted from different liquid manure treatments

\begin{tabular}{lccc}
\hline Treatment & Odor intensity & Odor offensiveness & Odor concentration index \\
\hline \hline Fresh manure & $3.5^{\mathrm{b}}$ & $4.0^{\mathrm{b}}$ & $1,308^{\mathrm{b}}$ \\
Anaerobic digestion & $4.0^{\mathrm{a}}$ & $5.0^{\mathrm{a}}$ & $1,651^{\mathrm{a}}$ \\
Thermophilic aerobic digestion & $1.0^{\mathrm{c}}$ & $1.0^{\mathrm{c}}$ & $343^{\mathrm{c}}$ \\
\hline
\end{tabular}

a,b,c Mean values with different superscript letters are significantly different $(\mathrm{p}<0.01)$ 
다면 고온 호기성 소화에 의한 액비는 냄새와 관련되어 별다른 문제가 없을 것으로 판단된 다. 반면, 신선분뇨나 혐기성 소화에 의한 액비 는 공정규격에 미달됨은 물론 자가 농경지에 살포시에도 악취 휘산에 의한 민원 발생의 가 능성이 있을 것으로 판단된다. 관능법에 의한 악취 강도 및 불쾌도 평가들이 실험방법 및 절 차에 따라 그 결과가 상이하게 나타날 수 있 고, 악취 평가원들이 감지하는 후각 민감도의 차이에 의해 다소 주관성이 개입될 수 있는 평 가법이지만, 기타 다른 오염물질 중 악취만은 감각 공해로 분류될 만큼 실질적인 악취 민원 을 제기할 수 있는 인간의 후각을 이용한다는 측면에서 기기분석법과 더불어 평가결과에 대 한 상호간 비교를 병행할 필요성이 있다고 사 료된다.

\section{2. 처리방법에 따른 액상분뇨 유래 암모니아 및 황화합물 악취물질 측정}

처리방법에 따라 액상분뇨에서 휘산되는 암 모니아 $\left(\mathrm{NH}_{3}\right)$ 의 농도는 신선분뇨에서 29.94 , 혐 기적 소화 액상분뇨에서 10.57 및 고온 호기성 소화에서 $1.34 \mathrm{ppm}$ 의 농도로 분석되었으며, 처 리방식에 따라 통계적으로 유의적인 차이를 보 였다(Table 4). 암모니아는 혐기 - 호기적 조건 에서 모두 생성되며, 대기 중 암모니아의 $80 \%$ 이상이 축산에서 방출되고 있어 암모니아 휘산 을 경감하기 위한 분뇨 관리 및 살포방식에 대한 연구가 진행되어져 왔다(DEFRA, 2001; Arogo, 2002). 암모니아는 황화수소와 같이 축산에서 발생되는 대표적인 악취물질로 간주되고 있으
나 연구자들에 따라 최소감지농도(odor threshold value)가 0.037 46.8 ppm의 큰 변이(WPCF, 1985; 양 등, 1998)를 나타낼 뿐만 아니라 쉽게 희석 되기 때문에 인간이 느끼는 악취 불쾌감 형성 에 크게 기여하는 악취성분은 아니라 하였다 (김 및 최, 2001). 또한 퇴비공장에서 발생된 악 취평가 연구에서 공장 내의 암모니아 농도가 200 400 ppm으로 높았지만 인근 주변마을에서 는 암모니아가 검출되지 않았고, 발생원 외부 에서는 크게 문제시되지 않았다고 보고하였다 (한강수계관리위원회, 2002). 이러한 연구 결과 와 악취성분이 확산정도가 크지 않고 최소감지 농도 이하로 쉽게 대기 중에서 희석되는 암모 니아의 특성을 고려해 본다면 본 연구에서 수 행된 처리방법이 다른 액상분뇨에서 발생된 암 모니아는 악취형성에 주된 영향을 미치는 원인 물질은 아니라고 사료된다.

Fig. 1은 액상분뇨에서 발생되는 황화합물 악 취물질을 측정하기 위해 GC-PFPD로 분석한 크 로마토그램을 나타난 것이다. 일반적으로 가축 분뇨에서 유래된 황화합물 악취물질은 $\mathrm{ppb}$ 단 위의 소량으로 방출되며, 금속성 물질과의 강 한 흡착성 때문에 시료의 포집과 분석에 최적 의 조건을 선택하고 유지시키는 것이 중요하 다. 현재 악취 발생원으로부터 황화합물을 분 석하기 위해 유리용기, 마일러 백, 알루미늄 백 및 테들러 백 등이 시료 채취용기로 사용되고 있는데, 황화합물은 시료 채취용기의 내면에 흡착되기 쉽고, 대기 중의 공기와 산화가 잘 일어나기 때문에 알루미늄 백이나 canister와 같 은 용기는 황화합물 채취용기로서 다소 부적합 하다(양 및 이, 1997). 따라서 본 연구에서는 화

Table 4. Mean concentrations of ammonia and sulfur containing compounds emitted from different liquid manure treatments

\begin{tabular}{lccccc}
\hline Treatment & $\begin{array}{c}\text { Ammonia } \\
(\mathrm{ppm})\end{array}$ & $\begin{array}{c}\text { Hydrogen } \\
\text { sulfide }\end{array}$ & $\begin{array}{c}\text { Methyl } \\
\text { mercaptan } \\
(\mathrm{ppb})\end{array}$ & $\begin{array}{c}\text { Dimethyl } \\
\text { sulfide }\end{array}$ & $\begin{array}{c}\text { Dimethyl } \\
\text { disulfide }\end{array}$ \\
\hline \hline Fresh manure & $29.94^{\mathrm{a}}$ & $108.63^{\mathrm{a}}$ & $3.12^{\mathrm{b}}$ & $0.88^{\mathrm{b}}$ & $0.49^{\mathrm{a}}$ \\
Anaerobic digestion & $10.57^{\mathrm{b}}$ & $65.93^{\mathrm{b}}$ & $18.55^{\mathrm{a}}$ & $5.26^{\mathrm{a}}$ & $0.33^{\mathrm{a}}$ \\
Thermophilic aerobic digestion & $1.34^{\mathrm{c}}$ & $5.15^{\mathrm{c}}$ & $0.97^{\mathrm{c}}$ & $0.80^{\mathrm{b}}$ & $0.56^{\mathrm{a}}$ \\
\hline
\end{tabular}

$\overline{a, b, c}$ Mean values with different superscript letters are significantly different $(\mathrm{p}<0.01)$. 


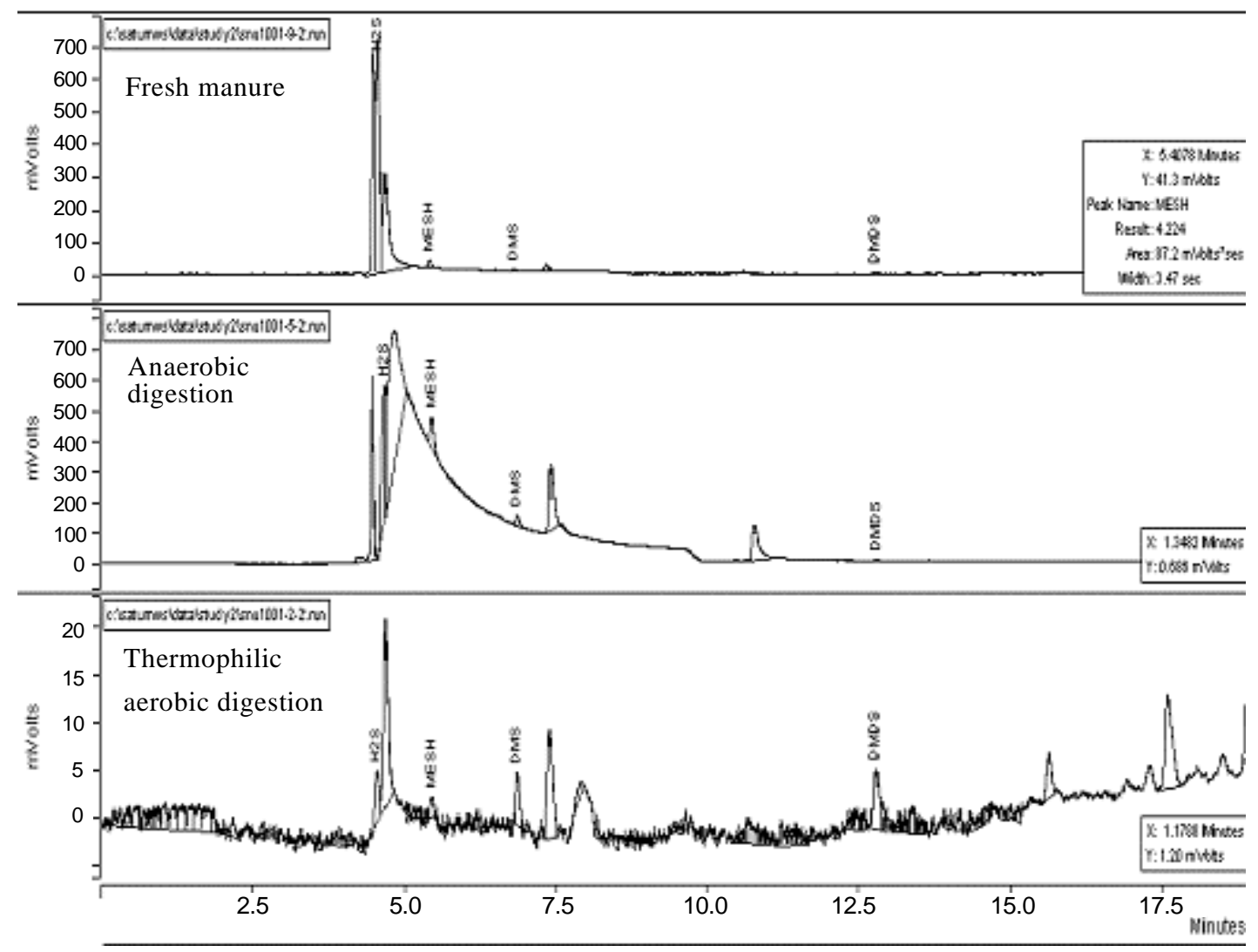

Fig. 1. Comparison of GC-PFPD chromatogram of sulfur containing compounds emitted from different liquid manure treatments

학적 반응이 안정하여 시료외 성분에 의한 변 성이 적은 폴리프로필렌 테들러 백을 이용하여 시료를 포집하였고, 황화합물 악취물질 분석을 위해 가장 적합하다고 제시되고 있는 GG-PFPD 를 이용하였다. 그러나 GC-PFPD를 이용한다 하더라도 악취물질 분석시 물질사이에 이상 피 크가 발생하여 인접한 물질의 분석결과에 영향 을 미칠 가능성이 있으며, 본 연구에서도 그러 한 분석상의 오차를 확인할 수 있었다. 고로 본 연구에서는 시료 중 황화합물 악취물질의 농도를 각각 3 반복 분석하여 평균값을 분석치 로 이용하였다.

처리방법이 다른 액상분뇨에서 발생되는 황화 합물 악취물질인 $\mathrm{H}_{2} \mathrm{~S}, \mathrm{MeSH}, \mathrm{DMS}$ 및 DMDS의 농도를 분석한 결과는 Table 4와 같다. DMS를 제외한 다른 황화합물 악취물질들은 처리방법
에 따라 통계적으로 유의적인 차이를 보였는 데, $\mathrm{H}_{2} \mathrm{~S}$ 는 신선분뇨에서 최고 농도인 108.63 $\mathrm{ppb}, \mathrm{MeSH}$ 와 DMS는 혐기성 소화 액상분뇨에 서 각각 18.55 및 $5.26 \mathrm{ppb}$ 의 농도로 검출되었 다. 황화합물 악취물질들이 축산에서 발생될 수 있는 악취와 관련되어 중요한 물질로 인식 되고 있는데, 이러한 이유는 가장 낮은 최소감 지농도(odor threshold value)을 가진 10가지 물 질들 중에서 6 가지가 황(S)을 포함한 물질들이 기 때문이다(O'Neill 및 Phillips, 1992).

황화합물 악취물질 중 황화수소 $\left(\mathrm{H}_{2} \mathrm{~S}\right)$ 는 암모 니아와 더불어 축산에서 발생되는 악취물질 중 가장 특징적인 물질로써 강한 독성과 악취 가 스로 간주되고 있다(Tchobanoglous 및 Burton, 1991). $\mathrm{H}_{2} \mathrm{~S}$ 의 최소 감지 농도는 $0.47 \mathrm{ppb}$ 로 소 량이 대기 중에 존재하여도 악취를 유발하게 
되며(환경부, 2001), 장기 노출에서는 $300 \mathrm{ppm}$ 의 농도에서 치사를 유발할 수 있으며, $2000 \mathrm{ppm}$ 의 고농도에서는 몇 분간의 노출에서도 사망의 원인이 될 만큼 독성을 가지고 있다(Pomeroy, 1976). 본 연구에서 분석된 액상분뇨에서 방출 된 $\mathrm{H}_{2} \mathrm{~S}$ 농도는 모두 최소 감지 농도인 $0.47 \mathrm{ppb}$ 를 상회하는 결과를 보였지만 다른 악취물질과 의 상쇄작용으로 인해 악취 강도나 불쾌도에 미치는 영향이 상대적으로 줄어든 것으로 사료 된다. 또한 호기적 소화 액상분뇨는 미생물에 의한 황화물(sulfide)의 지속적인 산화(oxidation) 로 $\mathrm{H}_{2} \mathrm{~S}$ 는 상당히 저감된 결과를 보였다.

$\mathrm{MeSH}$ 는 $0.07 \mathrm{ppb}, \mathrm{DMS}$ 는 $3 \mathrm{ppb}$ 의 최소 감지 농도값을 가지고 있으며(환경부, 2001), 분뇨의 혐기성 조건에서 황산염(sulfate)이 황화물(sulfide) 로 환원되어 생성하게 된다. 일반적으로 $\mathrm{MeSH}$ 은 $\mathrm{H}_{2} \mathrm{~S}$ 와 더불어 혐기성 발효과정에서 휘발성 황(S) 악취물질의 $80 \%$ 가량을 차지하는 것으로 보고되었다(Banwant 및 Bremner, 1975). 본 연 구에서 수행된 관능법과 기기분석법의 결과를 고려할 때 혐기성 소화에 의한 액상분뇨에서 악취 강도와 불쾌도가 신선분뇨나 고온 호기성 소화 액상분뇨에 비해 높은 것은 $\mathrm{MeSH}$ 와 $\mathrm{DMS}$ 가 높은 농도로 존재하는 것과 동시에 다 른 악취물질과 결합하여 상승작용에 의한 악취 비산이 큰 것으로 사료되며, 이 부분에는 추가 적인 연구가 필요할 것으로 판단된다.

\section{3. 처리방법이 다른 액상분느를 밭 토양에 살포시 악취 강도, 불쾌도 및 농도 평가}

처리방법이 다른 액상분뇨를 밭 토양에 살포 했을 때 악취 강도, 불쾌도 및 농도에 대한 결
과는 Table 5에서 보는 바와 같다. 고온 호기성 소화에 의한 액상분뇨를 밭 토양에 살포시 관 능법에 의한 악취 강도 및 불쾌도는 간신히 감 지 할 수 있는 정도의 냄새로 평가된 반면 혐 기성 소화 액상분뇨를 살포 하였을 때는 분뇨 자체에서 방출되는 냄새보다는 조금 저감되었 지만, 여전히 강하고 불쾌한 냄새가 발생되고 있는 것으로 평가되었다.

일반적으로 밭 토양인 경우, 논 토양에 비해 배수조건이 좋은 미사질 토양으로 배수조건이 양호하고, 강우나 액비 시용에 따른 투과성이 좋다(Brady 및 Weil, 1996). 또한 토양에 환원된 액상분뇨 중의 유기물이나 악취 물질들이 토양 의 공극에 존재하는 수분에 희석되고, 이온들 과 흡착(absorption)되거나 토양 미생물에 의해 분해되는 다양한 과정을 통해 최종적으로 악 취가 저감될 수 있다. 그러나 토양의 여과율 (percolation rate)이 낮고 공극량이 적어 투수성 이 낮은 토양 조건에서는 토양내로 침투하지 못한 액상분뇨가 직접 대기와 반응하여 악취 물질이 더욱 신속하게 확산될 가능성도 있다. 본 연구에서도 Fig. 2에서 보는 바와 같이 동일 한 혐기성 소화 액상분뇨라 할지라도 논 토양 보다도 밭 토양에 살포된 액상분뇨에서 악취 강도와 불쾌도가 더욱 높은 것으로 평가되어 앞서 언급한 가능성을 실제로 확인할 수 있었 다.

\section{4. 처리방법이 다른 액상분뇨를 밭 토양에 살포시 암모니아 및 황화합물 악취물질 측정}

처리방법이 다른 액상분뇨를 밭 토양에 살포

Table 5. Comparison of odor intensity, offensiveness and concentration index from upland soil spreaded different liquid manure

\begin{tabular}{lccc}
\hline Liquid manure & Odor intensity & Odor offensiveness & Odor concentration index \\
\hline \hline Fresh manure & $2.5^{\mathrm{b}}$ & $3.0^{\mathrm{a}}$ & $449^{\mathrm{b}}$ \\
Anaerobic digestion & $4.0^{\mathrm{a}}$ & $4.0^{\mathrm{a}}$ & $602^{\mathrm{a}}$ \\
Thermophilic aerobic digestion & $1.0^{\mathrm{b}}$ & $1.0^{\mathrm{b}}$ & $102^{\mathrm{c}}$ \\
\hline
\end{tabular}

$\overline{\mathrm{a}, \mathrm{b}, \mathrm{c}}$ Mean values with different superscript letters are significantly different $(\mathrm{p}<0.01)$. 


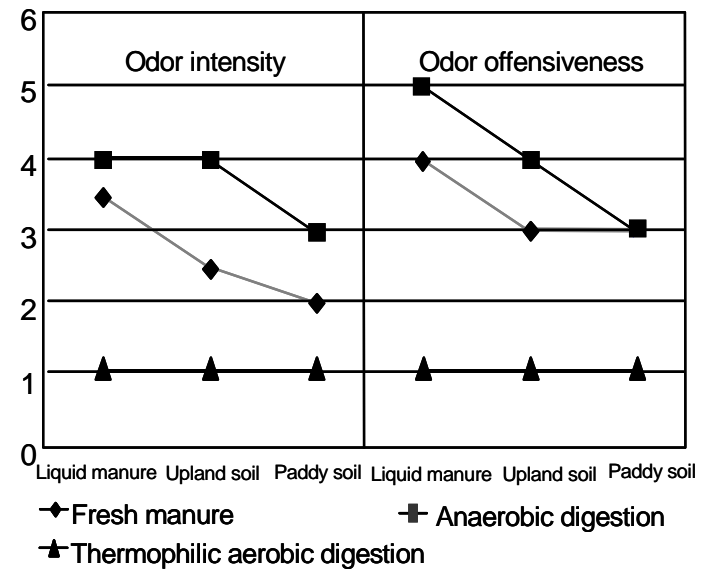

Fig. 2. Comparison of odor intensity and offensiveness emitted from different treated liquid manure, its application to an upland and paddy soil

시 휘산된 암모니아의 농도 비교결과는 Table 6 과 같다. 신선분뇨를 밭 토양에 살포 했을 때 는 $5.60 \mathrm{ppm}$, 혐기성 소화는 $2.72 \mathrm{ppm}$, 고온 호 기성 소화 액상분뇨는 $0.08 \mathrm{ppm}$ 의 농도로 분석 되었고, 액상분뇨의 특성에 따른 밭 토양에서 발생되는 암모니아의 농도가 통계적인 차이 $(\mathrm{p}<0.01)$ 를 보이는 것으로 나타났다. 본 연구에 서 적용된 살포 방식은 우리나라 농가에서 관 행적으로 이용하고 있는 토양 표면 살포방식을 적용하였는데, 액상분뇨의 처리방법에 따라 75 - 95\%의 암모니아 휘산 저감 효과를 보였다.

현재 우리나라는 농경지에 액비를 살포할 수 있는 적정 살포방식이나 살포기계가 널리 보급 되지 않았지만 가축분뇨의 토양 살포를 기본
개념으로 인식해온 외국의 경우에는 살포 방식 에 따른 악취 저감에 대한 연구가 상당히 진행 되어 왔다. DEFRA(2001)는 분뇨의 토양주입 (injection) 방법이 산파살포(broadcasting)에 의한 방법보다 $90 \%$ 가량의 암모니아 저감 효과가 있었다고 하였고, 토양 내 주입 깊이 $(3 \sim 30 \mathrm{~cm})$ 에 따라 74 94\%의 암모니아 휘산 저감 효과 가 있었다고 하였다(Hoff 등, 1981; Phillips 등, 1990; Smith 등, 2000). 이처럼 살포 방식에 따라 암모니아 휘산이 저감된 효과를 얻을 수 있는 이유는 가축분뇨의 토양내 침투력(infiltration)을 높여주고, 표면적을 줄여서 살포된 분뇨 표면 에 닿는 풍속을 감소시켜주는 물리적인 요인과 더불어 식물의 뿌리에 의한 암모니아 흡착, 잎 에 의한 휘산 작용 억제 때문이다.

처리방법이 다른 액상분뇨를 밭 토양에 살포 시 발생되는 황화합물 악취물질인 $\mathrm{H}_{2} \mathrm{~S}, \mathrm{MeSH}$, DMS 및 DMDS에 대한 분석 결과는 Table 6에 서 보는 바와 같다. 신선분뇨를 밭 토양에 살 포시 $\mathrm{H}_{2} \mathrm{~S}$ 의 농도가 $108.63 \mathrm{ppb}$ 에서 $2.27 \mathrm{ppb}$ 로 감소되었으며, 혐기성 소화는 $\mathrm{H}_{2} \mathrm{~S}$ 와 $\mathrm{MeSH}$ 농 도가 저감된 것으로 나타났다. 그러나 모든 처 리구에서 최소감지농도 이상의 농도로 검출되 었다. 밭 토양에 액상분뇨를 살포시 악취 형성 에 가장 크게 기여하는 황화합물 악취물질은 $\mathrm{H}_{2} \mathrm{~S}$ 와 $\mathrm{MeSH}$ 라고 사료되나 다른 어떤 환경조건 하에서는 2 분자의 $\mathrm{MeSH}$ 가 결합하여 1 분자의 $\mathrm{DMDS}$ 로 상호변환 될 수 있기 때문에 DMDS가 주요 악취발생 물질이 될 수도 있을 것으로 사 료된다.

황화합물 악취물질들은 분뇨의 저장과 처리

Table 6. Mean concentrations of ammonia and sulfur containing compounds from upland soil spreaded different liquid manure

\begin{tabular}{lccccc}
\hline Liquid manure & $\begin{array}{c}\text { Ammonia** } \\
(\mathrm{ppm})\end{array}$ & $\begin{array}{c}\text { Hydrogen } \\
\text { sulfide* }\end{array}$ & $\begin{array}{c}\text { Methyl } \\
\text { mercaptan* } \\
(\mathrm{ppb})\end{array}$ & $\begin{array}{c}\text { Dimethyl } \\
\text { sulfide }\end{array}$ & $\begin{array}{c}\text { Dimethyl } \\
\text { disulfide }\end{array}$ \\
\hline \hline Fresh manure & $5.60^{\mathrm{a}}$ & $2.27^{\mathrm{a}}$ & $0.87^{\mathrm{b}}$ & $1.03^{\mathrm{a}}$ & $0.56^{\mathrm{a}}$ \\
Anaerobic digestion & $2.72^{\mathrm{b}}$ & $2.58^{\mathrm{a}}$ & $1.58^{\mathrm{a}}$ & $0.81^{\mathrm{a}}$ & $0.43^{\mathrm{a}}$ \\
Thermophilic aerobic digestion & $0.08^{\mathrm{c}}$ & $0.75^{\mathrm{b}}$ & $0.32^{\mathrm{c}}$ & $0.93^{\mathrm{a}}$ & $0.57^{\mathrm{a}}$ \\
\hline
\end{tabular}

a,b,c Mean values with different superscript letters are significantly different $(\mathrm{p}<0.05)$.

* Significant at $\mathrm{p}<0.05$, ** Significant at $\mathrm{p}<0.01$. 
조건에 따라 생성되게 되는데, Banwart 및 Bremner(1975)는 생분뇨에서는 DMS만이 검출 되고 나머지 물질들은 검출되지 않았다고 하였 고, Hao 등(1996)은 혐기성 미생물에 의해 황산 염(sulfate)이 전자수용체로 이용되고 많은 양의 황화물(sulfide)이 생성되어 수용액의 $\mathrm{pH}$ 에 영향 을 받아 휘발성 황(S) 함유 악취물질들을 발생 하게 된다고 하였다. 황화합물 악취물질들은 혐기적 조건에서 methionine이나 cysteine 같은 황(S) 함유 아미노산의 분해 과정에서 발생되 기 때문에 분뇨에 산화제(oxidant)를 살포하거 나, 폭기(aeration)에 의한 호기적 조건을 유지시 켜 주는 것이 분뇨의 저장 과정과 처리과정에 서 황화합물 악취물질을 저감시킬 수 있는 효 율적인 방법이라 판단된다. 물론 액상분뇨를 토양에 살포하는 과정에서 황화합물 악취물질 이 대기 중의 공기와 반응하여 산화될 수 있으 며, 토양 피복 및 토양의 공극에 존재하는 공 기에 의해 산화되어 황화합물 악취물질이 저감 될 수 있다. 그러나 이러한 하향식(downstream) 저감방법 보다는 분뇨의 처리과정 중에 분뇨에 서 발생할 수 있는 악취물질의 농도를 최대로 낮추는 상향식(upstream) 저감방법이 액상분뇨 의 악취저감이라는 측면에서 더욱 바람직한 접 근이라고 생각된다.

\section{5. 처리방법이 다른 액상분뇨를 논 토양에 살포시 악취 강도, 불쾌도 및 농도 평가}

액상분뇨를 논 토양에 살포 했을 때 악취 강 도, 불쾌도 및 농도에 대한 결과를 Table 7에 나타내었다. 관능법에 의한 악취 강도 및 불쾌 도는 밭 토양과 비슷한 결과를 보였는데, 고온
호기성 소화 액상분뇨는 간신히 감지 할 수 있 는 정도의 냄새로 평가된 반면 혐기성 소화에 의한 분뇨를 살포 하였을 때는 여전히 쉽게 감 지할 수 있는 냄새로 평가되었다(<Fig. 2> 참 고).

일반적으로 액비 저장조를 설치한 경종농가 나 액비 발효조를 운전하는 축산농가에서 처 리된 액상분뇨에서 악취가 심하게 발생하는 것은 호기성 처리조건을 유지하지 못함은 물 론 혐기적 분해과정이 적절하게 이루어지지 않기 때문인 것으로 판단된다. 즉, 분뇨에 존재 하는 유기물들이 메탄균(methanogens)에 의해 메탄(methane)과 이산화탄소로 분해되지 않고 악취물질로 존재하기 때문이다(Zhu, 2000). 이 러한 원인은 우리나라의 계절별 온도 변이가 커서 최적의 메탄을 생성할 수 있는 중온성 미 생물 $\left(35^{\circ} \mathrm{C}\right)$ 의 생육 조건을 유지시키기 어렵기 때문이다. 또한 악취저감과 관련되어 사용된 첨가제가 효율적으로 악취 저감 효과가 발현될 수 있도록 분뇨의 적정 환경조건을 조성하고자 하는 이해와 실행이 부족함과 더불어 그 실용 성과 작용원리가 명확하지 않거나 검증되지 않 은 첨가제(additive)의 사용 때문이라 사료된다 (McCrory 및 Hobbs, 2001).

\section{6. 처리방법이 다른 액상분뇨를 논 토양에 살포시 암모니아 및 황화합물 악취물질 측정}

Table 8에 처리방법이 다른 액상분뇨를 논 토양에 살포시 발생되는 암모니아 및 황화합물 악취물질에 대한 분석결과를 나타내었다. 신선 분뇨를 논 토양에 살포 했을 때는 $16.31 \mathrm{ppm}$, 혐

Table 7. Comparison of odor intensity, offensiveness and concentration index from paddy soil spreaded different liquid manure

\begin{tabular}{lccc}
\hline Liquid manure & Odor intensity & Odor offensiveness & Odor concentration index \\
\hline \hline Fresh manure & $2.0^{\mathrm{b}}$ & $3.0^{\mathrm{a}}$ & $494^{\mathrm{b}}$ \\
Anaerobic digestion & $3.0^{\mathrm{a}}$ & $3.0^{\mathrm{a}}$ & $817^{\mathrm{a}}$ \\
Thermophilic aerobic digestion & $1.0^{\mathrm{c}}$ & $1.0^{\mathrm{b}}$ & $132^{\mathrm{c}}$ \\
\hline a,b,c Mean values with different superscript letters are significantly different $(\mathrm{p}<0.01)$.
\end{tabular}


Table 8. Mean concentrations of ammonia and sulfur containing compounds from paddy soil spreaded different liquid manure

\begin{tabular}{lccccc}
\hline Liquid manure & $\begin{array}{c}\text { Ammonia } \\
(\mathrm{ppm})\end{array}$ & $\begin{array}{c}\text { Hydrogen } \\
\text { sulfide }\end{array}$ & $\begin{array}{c}\text { Methyl } \\
\text { mercaptan } \\
(\mathrm{ppb})\end{array}$ & $\begin{array}{c}\text { Dimethyl } \\
\text { sulfide }\end{array}$ & $\begin{array}{c}\text { Dimethyl } \\
\text { disulfide }\end{array}$ \\
\hline \hline Fresh manure & $16.31^{\mathrm{a}}$ & $4.39^{\mathrm{a}}$ & $0.89^{\mathrm{a}}$ & $1.71^{\mathrm{a}}$ & $0.67^{\mathrm{a}}$ \\
Anaerobic digestion & $8.18^{\mathrm{b}}$ & $1.51^{\mathrm{b}}$ & $0.54^{\mathrm{ab}}$ & $1.28^{\mathrm{a}}$ & $0.52^{\mathrm{a}}$ \\
Thermophilic aerobic digestion & $0.12^{\mathrm{c}}$ & $1.35^{\mathrm{b}}$ & $0.36^{\mathrm{b}}$ & $0.84^{\mathrm{a}}$ & $0.50^{\mathrm{a}}$ \\
\hline
\end{tabular}

a,b,c Mean values with different superscript letters are significantly different $(\mathrm{p}<0.01)$.

기성 소화는 $8.18 \mathrm{ppm}$, 고온 호기성 소화 분뇨 는 $0.12 \mathrm{ppm}$ 의 농도로 분석되었고, 액상분뇨 특성에 따라 논 토양에서 발생되는 암모니아 의 농도가 통계적인 차이 $(\mathrm{p}<0.05)$ 를 보이는 것 으로 나타났다. 또한 액상분뇨의 처리방법에 따라 22 91\%의 암모니아 휘산 저감 효과를 보였다.

한편 황화합물 악취물질인 $\mathrm{H}_{2} \mathrm{~S}$ 는 신선분뇨 살포시 $108.63 \mathrm{ppb}$ 에서 $4.39 \mathrm{ppb}$ 로 감소되었으 며, 혐기성 소화는 $\mathrm{H}_{2} \mathrm{~S}$ 가 $65.93 \mathrm{ppb}$ 에서 1.51 $\mathrm{ppb}, \mathrm{MeSH}$ 는 $18.55 \mathrm{ppb}$ 에서 $0.54 \mathrm{ppb}$ 로 농도가 저감된 것으로 측정되었다. 그러나 모든 처리 구에서 최소감지농도(odor threshold value) 이상 의 농도로 검출되어 악취발생에 황(S) 함유 악 취물질들이 기여하고 있음을 알 수 있었다. 물 질별로는 $\mathrm{H}_{2} \mathrm{~S}$ 가 신신분뇨에서 가장 높은 농도 로 검출되었으며, $\mathrm{MeSH}$ 의 경우에는 신선분뇨 와 혐기성 소화에서 고온 호기성 소화 액상분 뇨보다 높은 것으로 분석되었다.

논 토양은 밭 토양에 비해 함수율이 높고 배수조건이 낮은 점토질 토양으로 여과율이 낮다(RDA, 1988). 즉, 배수능력이 양호한 사질 토와 점질토의 경우 $2.33 \sim 43.22 \mathrm{~mm} / \mathrm{day}$ 의 여과 율을 보이는 반면 배수조건이 나쁜 토양인 경 우는 $0.93 \mathrm{~mm} / \mathrm{day}$ 의 낮은 여과율을 보이게 되 며, 이러한 특성은 논 토양에 액비를 살포시 토양 내로 침투되지 못한 액비 내의 암모니아 가 대기 중으로 확산될 가능성이 크게 된다. 본 연구에서 동일한 액비 시료를 토양 특성이 다른 논.밭 토양에 살포시 암모니아의 휘산 정도를 비교해 보면 신선분뇨와 혐기성 소화
액상분뇨에서 방출되는 암모니아 농도가 밭 토 양에 비해 논 토양에서 높게 분석되어 이러한 가정을 뒷받침 하여 주고 있다. 가축분뇨를 토 양에 살포시 휘산되는 악취는 액상분뇨의 조성, 토양 조건 및 기후 등의 상호작용에 영향을 받 기 때문에(Sommer 및 Hutchings, 2001) 본 연구 에서 수행된 액상분뇨의 특성, 악취발생 평가 및 토양 조건만을 가지고 전술하기에는 부족 함이 있다. 그러나 고온 호기성 처리에 의한 액상분뇨는 액비 자체에서 발생될 수 있는 악 취 물질 방출이 적고, 토양에 살포시 인간이 감지 할 수 있는 최소감지농도 수준에 준하는 저감 효과를 보였다. 따라서 분뇨 유래 악취를 저감시킬 수 있는 액상분뇨 처리방법과 적정 살포 방법을 병행한다면 암모니아의 휘산 뿐 만 아니라 가축분뇨의 액비화 이용시 발생할 수 있는 악취로 인한 민원발생의 소지를 줄일 수 있어 궁극적으로 액비의 경축연계를 더욱 촉 진시킬 수 있을 것으로 사료된다.

$$
\text { IV. 요 약 }
$$

효율적인 악취방지책을 수립하고 시행하는 것은 지속가능한 축산 뿐만 아니라 증가되는 악취 민원과 더욱 엄격해지는 법규에 대응하기 위해 필수적이다. 본 연구는 돈분뇨의 처리방 법에 따른 액상분뇨 유래 악취 및 처리방법이 다른 액상분뇨를 토양에 살포시 발생하는 악취 및 악취물질을 평가하기 위하여 수행되었다. 시험에 사용된 액상분뇨는 신선 분뇨, 혐기성 소화 액상분뇨 및 고온 호기성 소화 액상분뇨 
를 이용하였고, 토양 특성이 다른 논/밭 토양을 대상으로 총 6처리 5반복 설계 배치하였다. 시 료 포집은 관능법과 기기분석법에 사용될 시료 를 각각 주사기와 테들러 백을 이용하여 액상 분뇨와 액상분뇨를 살포한 토양의 상부공간에 서 채취하였다. 악취 분석은 관능법을 이용하 여 악취강도 및 불쾌도를 평가하였고, 기기분 석법으로는 질소화합물 악취물질인 암모니아를 흡광광도법, 황화합물 악취물질인 황화수소, 메 틸머캅탄, 다이메틸설파이드 및 다이메틸다이 설파이드를 GC-PFPD를 이용하여 분석하였다. 처리과정이 다른 액상분뇨의 악취 및 악취물질 발생 평가에서 고온 호기성 소화 액상분뇨가 신선 분뇨 및 혐기성 소화 액상분뇨에 비해 악 취강도, 불쾌도 및 악취농도 저감 효과가 매우 두드러지게 나타났으며 통계적으로도 유의적인 차이가 인정되었다. 혐기성 소화 액상분뇨와 고온 호기성 소화 액상분뇨에서 발생되는 황화 수소, 메틸머캅탄, 다이메틸설파이드, 다이메틸 다이설파이드 및 암모니아의 평균농도는 각각 65.93 : $5.15 \mathrm{ppb}, 18.55$ : $0.97 \mathrm{ppb}, 5.26$ : 0.80 $\mathrm{ppb}, 0.33: 0.56 \mathrm{ppb}$ 및 $10.57: 1.34 \mathrm{ppm}$ 으로 분 석되었다. 액상분뇨를 밭과 논 토양에 살포시 혐기성 소화 액상분뇨와 고온 호기성 소화 액 상분뇨가 각각 51 94\% 및 22 91\%의 암모니 아 저감 효율을 나타내었다. 본 시험의 결과를 종합할 때 고온 호기성 소화 액상분뇨가 악취 저감이라는 측면에서 다른 처리방법에 비해 우 수한 것으로 나타났으며, 액상분뇨의 토양환원 에서 발생되는 악취문제는 액상분뇨의 처리방 법에 따른 악취발생 정도와 직접적인 연관이 있다고 사료된다.

\section{$\mathrm{V}$. 인 용 문 헌}

1. Arogo, J., Westerman, P. W., Heber, A. J., Robarge, W. P. and Classen, J. J. 2002. Ammonia emissions from animal feeding operations. National Center for manure and Animal Waster Management White Papers, North Carolina State University, Raleigh, N. C.
2. Banwart, W. L. and Brenmer, J. M. 1975. Formation of volatile sulfur compounds by microbial decomposition of sulfur-containing amino acids in soils. Soil Biol. Biochem. 7:359-364.

3. Banwart, W. L. and Brenmer, J. M. 1975. Identification of sulfur gases evolved from animal manures. J. Environ. Qual. 4:363-366.

4. Brady, N. C. and Weil, R. R. 1996. The Nature and Properties of Soils, 11th ed. Prentice Hall, New Jersey.

5. DEFRA(Department for Environment, Food \& Rural Affairs). 2001. Ammonia in the UK-Key points.

6. Hao, O. J., Chen, J. M., Huang, L. and Buglass, R. 1996. Sulfate-reducing bacteria. Critical Reviews in Environ. Sci. and Technol. 26(1):155-187.

7. Hardwick, D. C. 1985. Agricultural problems related to odor prevention and control. pp. 21-26. In Odor Prevention and Control of Organic Sludge and Livestock Farming. Edited by V. C. Nielsen, J. H. Voorburg, and P. L'hermite. Elsevier Applied Science Publishers, New York.

8. Hoff, J. D., Nelson, D. W. and Sutton, A. L. 1981. Ammonia volatilization from liquid swine manure applied to cropland. J. Environ. Qual. 10:90-95

9. Jacobson, L., Schmidt, D., Nicolai, R. and Bicudo, J. 1998. Odor control for animal agriculture. BAEU-17. Minnesota State Univ. Ext. Serv., MN.

10. Lorimor, J., Hoff, S. and O'Shaughnessy, P. 2002. Emission control systems. In: Iowa State University and The University of Iowa Study Group. (Ed.), Iowa Concentrated Animal Feeding Operations Air Quality Study. pp. 202-212.

11. Mackie, R. I., Stroot, P. G. and Varel, V. H. 1998. Biochemical identification and biological origin of key odor components in livestock waste. J. Anim. Sci. 76:1331-1342.

12. McCrory, D. F. and Hobbs, P. J. 2001. Additives to reduce ammonia and odor emissions from livestock wastes: A review. J. Environ. Qual. 
30(2):345-355.

13. NIOSH(National Institute for Occupational Safety and Health). 1994. NIOSH Manual of Analytical Method(4th Ed.). Cincinnati, Ohio.

14. O'Neill, D. H. and Phillips, V. R. 1992. A review of the control of odour nuisance from livestock buildings: Part 3, Properties of the odorous substances which have been identified in livestock wastes or in the air around them. J. Agr. Eng. Res. 53:23-50.

15. Pain, B. F. 1995. Odours from application of livestock wastes to land. In New Knowledge in Livestock Odor, Proceedings of International Livestock Odor Conference, Ames, Iowa. pp. 125 $-126$.

16. Pain, B. F., Phillips, V. R., Clarkson, C. R., Misselbrook, T. H., Rees, Y. J. and Farrent, J. W. 1990. Odour and ammonia emissions following the spreading of aerobically treated pig slurry on grassland. Biol. Waste 34(3):259-267.

17. Phillips, V. R., Pain, B. F., Clarkson, C. R. and Klarenbeek, J. V. 1990. Studies on reducing the odour and ammonia emissions during and after the land spreading of animal slurries. Farm Build. Eng. 7:17-23.

18. Pomeroy, R. D. 1976. The Problem of Hydrogen Sulfide in Sewers. London, England: Clay Pipe Development Assoc. Ltd.

19. Rappert, S. and Muller, R. 2005. Odor compounds in waste gas emissions from agricultural operations and food industries. Waste Manage. 25:887-907.

20. RDA(Rural Development Administration). 1988. Proceeding of $\mathrm{X} \mathrm{VIII} \mathrm{international} \mathrm{forum} \mathrm{on} \mathrm{soil}$ taxonomy and agrotechnology transfer. p. 374.

21. Roderick, I. M., Peter, G. S. and Vincent, H. V. 1998. Biochemical identification and biological origin of key odor components in livestock waste. J. Anim. Sci. 76:1331-1342.

22. SAS Institute Inc. 1999. SAS user's guide. SAS Inst., Inc., Gary, NC.
23. Smith, K. A., Jackson, D. R., Misselbrock, T. H., Pain, B. F. and Johnson, R. A. 2000. Reduction of ammonia emission by slurry application techniques. J. Agr. Eng. Res. 77(3):277-287.

24. Sommer, S. G. and Hutchings, N. J. 2001. Ammonia emission from field applied manured and its reduction-invited paper. European J. Agron. 15:1-15.

25. Sommer, S. G. 1992. Ammonia volatilization from cattle and pig slurry during storage and after application in the field. The Danish Institute of Plant and Soil Science. Denmark.

26. Svoboda, J. F. 1995. Aerobic treatment of livestock slurries. SAC Technical Note, Environmental Series No. 2.

27. Tchobanoglous, G. and Burton, F. L. 1991. Wastewater Engineering, Treatment, Disposal and Reuse. (3rd Ed.) Mcgraw-Hill Series in Water Resources and Environmental Engineering. New York, N. Y.: Metcalf \& Eddy, Inc.

28. Whitehead, T. R. and Cotta, M. A. 2004. Isolation and identification of hyper-ammonia producing bacteria from swine manure storage pits. Curr. Microbiol. 48:20-26.

29. Williams, A. G., Shaw, M., Slevaih, C. M. and Cumby, R. J. 1989. The oxygen requirements for deodorising and stabilising pig slurry by aerobic treatment. J. Agr. Eng. Res. 43:291-311.

30. WPCF. 1985. Odor Control for Wastewater Facilities: Manual of Practice No 22. Washington, D. C. Water Pollution Control Federation.

31. Zhu, J. 2000. A review of microbiology in swine manure odor control. Agr. Ecosyst. Environ. 78: 93-106.

32. 김기연, 최홍림. 2001. 한강유역내 축분퇴비공장 악취발생에 대한 현장 평가. 한국동물자원과학회 지. 43(6):1005-1018.

33. 농림부. 1997. 친환경농업육성법.

34. 농업과학기술원. 1999. 친환경농업을 위한 가축 분뇨 퇴비 · 액비 제조와 이용. pp. 157-168. 
35. 농촌진흥청. 2006. 농진청 고시 제2005-26호.

36. 농협중앙회. 2002. 양돈분뇨 액비이용 및 국내 유기축산 발전방향 세미나.

37. 양성봉, 이성화. 1997. 악취의 성분 분석. 동화기술.

38. 양성봉, 정영만, 서흥원, 김현정. 1998. 악취의 관 능측정. 도서출판 복

39. 축산관련단체협의회. 2003. “친환경 축산발전 과 제와 대책”, 제2회 축산발전을 위한 심포지엄. pp.13-25.
40. 한강수계관리위원회. 2002. 축산분뇨의 자동 퇴 비화 방안연구.

41. 한국유기농업학회. 2003. 21세기 친환경 순환농업 의 발전모델과 정책과제. 한국유기농업학회 2003 년도 상반기 심포지움.

42. 환경부. 2001. 악취물질 발생원 관리방안 개선을 위한 조사연구.

43. 환경부. 2005. 악취방지법.

(접수일자 : 2006. 3. 8. / 채택일자 : 2006. 4. 20.) 